Studia Maritima, vol. XXXI (2018)

ISSN 0137-3587

DOI: $10.18276 / \mathrm{sm} .2018 .31-02$

Jakub Morawiec*

\title{
ILLVIRKJAR OK ÓSKÍRĐIR. EIRÍKSDRÁPA BY MARKÚS SKEGGJASON AS AN EXAMPLE OF USING THE MOTIF OF THE SLAV-PAGAN IN THE SCANDINAVIAN MEDIEVAL LITERATURE
}

Keywords: poetry, paganism, Slavs

\section{Summary}

The article presents Eiriksdrápa, a poem dedicated to Erik the Good, king of Denmark (1095-1103), written by Markús Skeggjason, an Icelandic poet. The poem graced the visit of Jón Qgmundarson in Lund w 1105, where the local archbishop Gizurr ordained him Bishop of Hólar. The poem glorifies King Erik's achievements that indicate the Christian character of his rule, which was additionally confirmed by obtaining consent to create a new Archdiocese in Lund and by the king's pilgrimages to Rome and the Holy Land. The Christian dimension of Erik's rule is also reflected in the motif of his military actions against the pagan Slavs; it occupies a prominent place in Markús's poem and is analysed in the present article. The motif depicts the Slavs as traitors (svikmenn) and pagans (heiðnar), who were a threat to the peace in the kingdom. Erik's lack of mercy to them proved his just and pious rule in Denmark. The motif in question turned out to be very useful in the process of building up an image of a Christian ruler; on the other hand, it shows the artistic skills of Markús, based on the oeuvre of other poets who also described the pagan Slavs.

* dr hab. Jakub Morawiec, Uniwersytet Śląski w Katowicach, Instytut Historii, kubmo@wp.pl. ORCID: 0000-0003-3942-0566. 
The Slavs and the Scandinavians being neighbours and making use of the same Baltic Sea, must have had frequent and intensive relations in the Middle Ages. We learn about migrations, economic contacts and cultural transfers mainly thanks to archaeological research. On the other hand, we learn about political or military events much less, which results from the scantiness of written sources. However, the Scandinavian historiographic tradition of the Middle Ages created a motif of the Slav (Vinðr) that constituted an important element concerning the memory of particular people or key events, even though the Slavs were outside the native oecumene (Vinðland). Suffice it to recall the legend of the Vikings from Jomsborg or the tradition of the Slavic connections of the Norwegian king Olaf Tryggvason, as examples of the trend, which brought about a double - and self-contradictory - image of the Slavs. On the one hand, it refers to the King Burysław and his daughters, who commanded due respect and the ruler was considered powerful, in spite of being a pagan. That was why the King of Denmark Sweyn Forkbeard or Jarl of Jomsborg Sigvaldi considered it an honour to become a son-of-law of Burysław. The most significant battles of the medieval Northern Europe, at Hjørungavåg and Øresund, were fought with an active participation of Slavic troops. On the other hand, the status of the Slavs as pagans was negative. It was revealed in the tradition of the holiness of Olaf Haraldsson, king of Norway. The Slavs were presented not only as enemies of the only faith but also as a permanent threat to the Christian inhabitants of the North. Still the intercession of the saint king guaranteed them safety and protection. ${ }^{1}$

That trend is represented by the poem entitled Eiriksdrápa (a poem about Erik) written by an Icelandic poet Markús Skeggjason dedicated to Erik Sveinsson (1095-1103), king of Denmark, known as Eric the Good. The poem is being analysed in this article. It is exceptional, at least in two aspects. Firstly, it may be the most extensive example of the court poetry that has survived, dedicated to the ruler of Denmark. Secondly, one of the main roles is played by a motif of the Slav-pagan.

Markús was - as most skalds - of Icelandic origin. The date of his birth is unknown. He came from a respected and powerful family, which is proved by the fact that between 1084 and 1107 - to be exact October 15th, 1107 when he died - Markús fulfilled the function of legal speaker (lögsögumaðr) at the general

More at: J. Morawiec, "Slavs and their lands in Old Norse literature", in: Scandinavian Culture in Medieval Poland, eds. S. Moździoch, B. Stanisławski, P. Wiszewski (Wrocław 2013), 53-63. 
assembly (Alpingi). Ari Porgilsson, the author of Íslendingabók (Books about the Icelanders), mentions him among the ones on whose authority and knowledge he based his story about the origins of the Icelandic settlement and about the previous legal speakers. Ari emphasises that it was thanks to his support Bishop Skálholt Gizurr Ísleifsson introduced the tithe in 1096, the first regular tax in the history of the Island ${ }^{2}$. The author of another saga Kristni sagi (Conversion into Christianity) underlines that Markús was one of the most outstanding legal speakers in Iceland. ${ }^{3}$ There are many proofs that he was not the only poet in his family. The authors Morkinskinny, Fagrskinny and Heimskringli quote a strophe dedicated to the King of Norway Harald (Haraldr Sigurðarson, given the epithet Hardrada), the author of which was supposed to be Pórarinn Skeggjason, probably Markús's brother. ${ }^{4}$ The latter was associated by Skáldatal with two rulers of Denmark - Knud den Hellige (1080-1086) and the above mentioned Erik Sveinsson - and with the King of Sweden Ingi Steinkelsson (died probably in 1100). ${ }^{5}$ Yet that tradition is not reliable and it is quite possible that it was borne as a result of the circumstances in which Eiriksdrápa was composed and presented.

Even though the poetic oeuvre of Markús is not impressive (at least in the form we know it today), it is worth mentioning his texts were used not only as a reliable 'voice from the past' (first of all in Knýtlinga saga), but also as a refined and exemplary case of poetic art (first of all in Snorri's Edda and the Third Grammatical Treatise). In addition to the poem dedicated to Erik, the oeuvre of Markús includes one half-strophe from the poem that may have been dedicated to Knud den Hellige, two fragments (helming and couple/couplet) that may have come from the poem dedicated to Christ and two loose strophes (lausavisur). ${ }^{6}$

Contrasted with such a background Eiriksdrápa appears to be outstanding; it contains 32 strophes ${ }^{7}$ composed in hrynhent metre. ${ }^{8}$ Most strophes (28) have survived in Knytlinga sagi, the remaining four were quoted by Snorri Sturluson

2 J. Benediktsson, ed., Íslendingabók, Landnámabók. Íslenzk fornrit 1 (Reykjavík 1968), 22-23.

3 S. Grønlie, ed., Íslendingabók, Kristni saga (London 2006), 52.

4 K.E. Gade, ed., Scandinavian Poetry of the Middle Ages, Poetry from the Kings' Sagas 1. From c. 1035 to c. 1300, vol. 1-2 (Turnhout 2009), 294-295 (further SPMA II).

5 J. Sigurðsson et al., eds., Edda Snorra Sturlusonar. Edda Snorronis Sturlaei, vol. 3 (Copenhagen 1887), 258, 267.

6 SPMA II, 432.

7 It is conceivable that particular half-strophes thus edited following the example given by the author of Knýtlinga sagi, originally were full strophes.

8 On metres cf.: J. Morawiec, Między poezją i polityka. Rozgrywki polityczne w Skandynawii XI wieku wświetle poezji ówczesnych skaldów (Katowice 2016), 43. 
in his $E d d a .{ }^{9}$ The poem describes the achievements of King Erik, and is regarded as the most reliable source on his rule, at least by Óláf Pórðarson (probably the author of Knýtlinga sagi) and Saxo Grammaticus. ${ }^{10}$

The circumstances of composing and presenting the poem that I am interested in are especially engaging. Magnus Olsen's proposal dating back to the 1920s has not been challenged ${ }^{11}$ just the reverse, successive commentators of Eiriksdrápa have found it attractive. ${ }^{12}$ It is justified to claim that Markús composed the poem dedicated to Erik on the occasion of his trip to Denmark, which took place in 1105. He might have accompanied Jon Qgmundarson, who was to be ordained in Lund the first bishop of Hólar by Qzzur, the local archbishop. It was special time. The Metropolis of Lund was created just two years before as a result of the negotiations of Erik with the Roman Curia. It was a special award for the Scandinavian Church. The status of a separate province was not only a sign of recognition of achievements in Christianisation of the region but it also made the local hierarchs independent from the Archbishopric in Hamburg-Bremen, the fact the latter hardly accepted for a long time.

In summer 1103 Erik, during his pilgrimage to the Holy Land, died in Cyprus. When Jon (and probably Markús too) was arriving in Lund, Niels, Erik's brother and the youngest of Swen (Estridsen) Ulfsson's sons, was the ruler of Denmark. ${ }^{13}$ The régime of the brothers who one after another took the throne might hardly be considered peaceful and stable. Rebellions of subjects and the sibling rivalry resulted in dramatic events such as the murder of Knud IV in the St Alban Church in Odense. The murder had been preceded by a rebellion, which was probably inspired by the brother of the future saint, Olaf, who had been imprisoned by Knud and sentenced to exile in Flanders, where his father-in-law was the ruler. When his brother died Olaf succeeded to the throne and it coincided with crop failure and hunger; that is why Olaf earned the appellation 'Hunger', and his disastrous

SPMA II, 433.

10 Cf.: B. Gudnason, "Saxo och Eiríksdrápa", in: Nordiska studier i filologi och lingvistik. Festskrift tillägnad Gösta Holm på 60-årsdagen den 8 juli 1976, eds. L. Svensson et al. (Lund 1976), 127-137.

11 M. Olsen, "Lovsigemanden Markus Skeggesøns arvekvæde", Edda 15 (1921): 166.

12 J. Jesch, "Old and New in Markús Skeggjason's Eiríksdrápa", in: Scandinavia and Christian Europe in the Middle Ages. Papers of the 12th International Saga Conference Bonn/Germany, 28th July 2nd August 2003, eds. R. Simek, J. Meurer (Bonn 2003), 73; SPMA II, 432.

13 I. Skovgaard-Petersen, "The Making of Danish Kingdom", in: The Cambridge History of Scandinavia. Volume 1, Prehistory to 1520, ed. K. Helle (Cambridge 2003), 180-181; M.H. Gelting, "The Kingdom of Denmark", in: Christianization and the Rise of Christian Monarchy. Scandinavia, Central Europe and Rus' c. 900-1200, ed. N. Berend (Cambridge 2007), 95. 
rule was interpreted as a punishment for the murder of his saint brother; finally on August 18th, 1095 he was murdered too under unclear circumstances. ${ }^{14}$ The rule of Erik raised hopes for political stabilisation and strengthening of the Kingdom. His portrayal, which emerges from the few sources (first of all Gesta Danorum), might have been exaggerated and - what is more important - idealised. However, it shows that law was respected, unjustified military expeditions were given up and there were forces that wanted the dynasty to be stronger. Such aspirations might be achieved by means of canonisation of Knud IV or establishing a separate ecclesiastic metropolis. Erik was successful in both questions. His sudden death and - what is more - far away from his country might have led to squandering those achievements. The Danish Church hoped that Niels, the new ruler, would continue his brother's policy, which can be seen in the appeal and dedication of Ælnoth from Odense in his Vita et Passio Sancti Canuti..$^{15}$

Ordaining an ordinary of the newly created Icelandic diocese was a perfect occasion to emphasise the rank of the new ecclesiastic metropolis in Lund. And so was the appropriate commendation of the late King, who had directly contributed to augmenting the importance of the local bishopric. Markús Skeggjason's Eiriksdrápa might have been a gift on the part of Jon to Qzzur given as an expression of his gratitude for an awaiting award. Consequently it may be assumed that the way in which Erik was depicted in the poem by the Icelandic skald fully satisfied the expectations of both the King and the Archbishop.

As Judith Jesch has aptly remarked the poem by Markús is the oldest known case where hrynhent metre was used, which before could only be found in the poetry by Arnór Pórðarson, a skald working, inter alia, for Magnus den Gode, the king of Norway and Denmark, who is rightly regarded as the creator of that metre. ${ }^{16}$ It is quite possible that the choice of the metre was not accidental. Markús chose a tool which was not only inspired by the liturgy of the time, but also - or even first of all - already used by Arnór in a similar situation, namely making King Magnus rise to fame, among other things on the basis of his consanguinity with his predecessor, Olaf Haraldsson den Hellige.

\footnotetext{
14 Skovgaard-Petersen, “The Making”, 181.

15 Ibidem.

16 Cf.: Morawiec, Między poezja, 239.
} 
The poem conveys a mourning mood, which is visible in strophes 29 and 32:

Andar krafði út í lǫndum

alls stýrandi konung snjallan,

elli beiðat ofvægr stillir, aldar stríð es fregit víða; síðan harma siklings dauða snjallir menn of heimsbyggð alla, drúpir herr at dolga steypi dyggvan, pat tér verǫld hryggva. ${ }^{17}$

The one who rules everything has called the soul of the wise king in faraway countries, the powerful monarch had not lived to a ripe old age, lamentation can be heard everywhere; afterwards sages all over the world are lamenting over the death of the King, people bow down before the skilful vanquisher of enemies; the whole world is sad.

Fjarri hefr at fœðisk dýrri flotna vơrrr á élkers botni
- họva leyfir hverr maðr ævi hringvarpaðar - gjalfri kringðum. ${ }^{18}$

It is impossible for a more important defender of sea warriors to have been born on the bottom of a boat on stormy waves; everybody glorifies the noble life of the one who has thrown away his rings.

Some time ago Judith Jesch described the poem by Markús as an example of a clash of classical skaldic stylistics with new elements or new meanings. ${ }^{19}$ The above presented strophes confirm that opinion. The skald, according to the convention, puts Erik before other rulers, both the ones preceding him and the ones who were to succeed him. That elevation is maximised to a pompous level when we learn that the late King is being bewailed not only by his subjects and his troops but also by the whole world (allr heimsbyggd, verold). ${ }^{20}$

These strophes are a perfect example of how Markús aptly constructed the kennings describing the features of the ruler, elegantly balancing between gallantry, generosity and the concept of rex iustus. An example of that may be found in the phrase dyggvan steypi dolga (an apt vanquisher of enemies), which can be interpreted as a commendation of Erik's abilities, both the military ones and his

17 SPMA II, 458.

18 Ibidem, 460.

19 J. Jesch, "Old and New", 268-270.

20 On the other hand, in the poem there are no references to the close relations that connected the poet and the ruler, which was typical of the convention of erfikvaedi. It may indicate not only the imitative nature of the tradition kept in Skaldatal (there is no information on Markús's service for Erik or any other Scandinavian monarchs), but also the rightness of the guess that the poem was composed in Iceland and written and brought to Denmark by Jón. 
skills at keeping peace in his kingdom. The kenning dýrr vordr flotna (an important defender of sea warriors) may be interpreted in the same way. The basic word (vordr) in most cases had been used in the kennings of a just and caring monarch, but in this very case the word that determines the whole of the kenning (flotnar) indicates rather the military character of the phrase. Another intriguing example of Markús's poetic style is the phrase foðir fremðarráða (the one who feeds the wonderful achievements). Whereas the basic word (foedir) is typical of the kennings of the warrior, possibly a gallant ruler, the word that determines Markús's phrase - somehow exceptional in the corpus of the poetry - indicates an outstanding king that deserves to be remembered.

Thus Judith Jesch's remark refers also to the ways thanks to which Markús exalts Erik's merits. In addition to commendations typical of the skaldic style of the King's gallantry (hildarramr sløngvir harra in strophe 5; valdari sigrs in strophe 6; hróðigr beiðir brynpings in strophe 7) and generosity (orr, mildingr in strophes 5 and 16), there appear new elements, first of all referring to his eloquence and intellect. Erik's merits are presented in the best way in strophe 7:

Hróðigr átti brynpings beiðir bjartan auð ok froknligt hjarta minni gnógt ok manvit annat mest; fylgðu pví hvergi lestir; alla hafði oðlingr snilli, ungr nam hann á margar tungur, Eirekr vas, sás mátti meira, mestr ofrhugi, jǫfri flestum. ${ }^{21}$

The one who enjoyed fame, who arranged meetings of chainmailles, who possessed wealth and a brave heart, an extensive memory and other intellectual attributes to the highest degree; there was no room for defects; the ruler had all the wisdom because as a young boy he mastered many languages, Erik, who could do more than most rulers, was the bravest.

One of terms that defines the merits of the ruler is the noun snilli. The word has many meanings, but the majority of them refer to wisdom, eloquence and cleverness. The work is closely related to the adjective snjallr, which also contains a wide range of meanings from gallantry, through wisdom and magnificence to strength. Whereas the adjective snjallr appears already in the poetry of the turn of the 10th and 11th centuries to depict the ruler (e.g. Óláfsdrápa erfidrápa Tryggvasonar by Hallfreð Ottarsson) and is commonly used by the poets of the 11th 
century, the term snilli is much less frequently used by skalds and before Marcus's poem it appeared only once, in the poetry of Sigvat Pórðarson (Óláfsdrápa erfidrápa Haraldssonar). It might mean that Eiriksdrápa was one of the oldest texts in which the image of the ruler was created on the basis of his education in the medieval Scandinavia. The phenomenon - in a much more extensive form - is known in the subsequent centuries, including Konungs skuggsjá. Consequently, there appears a question of the skald's inspiration. It seems that in this case the point is that the poet fulfilled the expectations of the receivers of the poems in the Archdiocese of Lund. Markús introduces such novelties on the basis of the probably known and widely-held patterns; for example in strophe 7 there is a motif of a young ruler (ungr), whose age (in that case not defined) together with his skills indicates his exceptionality. Similar solutions might be found in other, quite often outstanding poets, whose oeuvres must have been an example for Marcús (Sigvatr Pórðarson, Arnórr Pórðarson, Ottarr svarti, bjóðólfr Arnasson). ${ }^{22}$ In the classical approach, the rulers exalted by skalds, still at a very young age showed military or sailing skills. In the case of Erik the most important element is the strength of his intellect and not the one of his sword, although the final phrase - mestr ofrhu$g i$-indicates that Markús did not want to give up the accepted canon altogether.

The way of exalting the ruler by referring to the gifts he was given by other rulers should be considered a significant novelty. In this context it is worth quoting strophe 28, in which Markús talks about the meeting of Erik and Alexios I, Byzantine emperor (although his name is not mentioned):

Hildingr pá við hæst lof aldar

hǫfgan auð í gulli rauðu

halfa lest af harra sjǫlfum

harða vitr í Miklagarði; áðan tók við allvalds klæðum

Eirekr, bó vas gefit fleira, reynir veitti herskip hǫnum hersa máttar sex ok átta. ${ }^{23}$

A very wise king was exalted to the highest possible degree not only by poetry but with heavy red gold, half a last, from the ruler of Constantinople himself; before Erik had received garments from the powerful ruler, now he was given even more, the one who tries the power of hersar has given him six and eight war boats.

22 Cf.: J. Jesch, "YYouth on the Prow'. Three Young Kings in the Late Viking Age", in: Youth in the Middle Ages, eds. P.J.P. Goldberg, F. Riddy (York 2002), 123-140; Morawiec, Między poezja, 200.

23 SPMA II, 457. 
Kloeði, herskip and rauðr gull are juxtaposed by the skald with fame (lof aldar). Undoubtedly, in this context the one who gives presents is essential and so is the fact that the presents given by the emperor were not incidental as it is indicated at the beginning of the second helming (áðan). The merits of the ruler and the respect on the part of others equally important monarchs justified Erik's decision to perform praiseworthy deeds, at the same time revealed the reasons why the deeds turned out to be the King of Denmark's success, the first of which was the erection of the Archbishopric in Lund. Markús devotes four strophes of his poem to that event. Even though they did not constitute a whole,${ }^{24}$ their overtones are uniform:

Eirekr náði útan fora erkistól of Saxa merki; hljótum vér, pats hag várn bœtir, hingat norðr at skjǫldungs orðum..$^{25}$

Erik was able to bring the Archbishopric from abroad, through the frontier with the Saxons; we, here in the North, are receiving what improves our situation according to the King's message.

Eyðisk hitt, at jafnstórt ráði

annarr gramr til pyrftar mǫnnum; leyfði allt, sem konungr krafði, Krists unnanda páfi sunnan. ${ }^{26}$

No other ruler will do so much to satisfy people's needs; the pope of the South gave the one devoted to Christ everything he had asked for.

Víða setti vísdóms grœðir

virki skrýddar hǫfuðkirkjur, gørva lét par hollvinr herjar hrein musteri fimm af steini; vǫru pau með tryggðar tíri tíða flaust, es gramr lét smíða bǫðvar snjallr ok beztr at ǫllu, borði merkð, fyr Saxland norðan. ${ }^{27}$

The one who is wise funded five richly ornamented cathedrals, a reliable friend of people, ordered to build five shining stone cathedrals; boats of sacraments, which the king, experienced in battle and the best at everything, ordered to build in the aura of safety north of Saxony, were decorated with wood.

${ }^{24}$ Yet it is not certain. The conclusion is based on the state the poem had survived in Knýtlinga saga. Its author treats two helmings (strophes 11 and 12) separately, which originally might have constituted one compositional whole, which is indicated in their common theme and their solemn character.

25 SPMA II, 442 (strophe 11).

26 Ibidem, 443 (strophe 12).

27 Ibidem, 452 (strophe 23). 
Dróttinn lét í Danmǫrk settan, dọglings grundar, skammt frá Lundi erkistól, panns oll pjóð dýrkar, eljunpungr, á danska tungu;

hildingr framði heilagt veldi, hvargegnan má Qzur fregna

- họnum vísar haulda reynir himna stíg - til byskups vígðan. ${ }^{28}$

The charismatic king ordered to establish the archbishopric in Denmark near Lund, which all the subjects of the king exalt in the Danish tongue; the ruler went to the holy kingdom; it is heard that the reverend Qzurr was ordained bishop, the one who puts the hosts to tests shows him the way to heaven.

The above presented strophes without a shadow of doubt show Markús's intentions to depict Erik as the man of the moment for the newly created Archdiocese. The king's attitude, concentrated on the noble work was probably supposed to be a model of relations between the state and the church. What is more, the royal initiative was presented as a sign of Erik's care for his subjects. A faithful friend of people appears as an ardent donor. Thus, the ruler's generosity was transferred to another level, so far hardly present in the skalds' poetry. The subjects are expected to enjoy the magnificent richly ornamented stone cathedrals in the same way as if the king himself had given them some gifts. The five new churches (the skald must have meant the cathedrals of the diocese) were to permanently define Erik's kingdom and its national dimension. The poet's words about all the subjects of the king (oll pjóð) exalting the ruler's decision in the Danish tongue (á danska tungu) should be understood in that way.

The contents of the above strophes suggest that Markús built his poetic message not only on the basis of the patterns present in the oeuvres of previous poets. A significant source of inspiration for the skald were the expectations on the part of the receivers of the poem in Lund, who were to be the first to see the effects of the poet's efforts. We do not know the circumstances of the process, but we are fully entitled to figure them out. Bishop Jón Qgmundarson might have had a part to play so that Markús's poem would impress the public. The efforts aiming at establishing a new diocese in Iceland since the beginning subordinated to the newly created archdiocese might have become an occasion to give the poet, also engaged in that process, appropriate contents, which were to reveal the king of Denmark's achievements in a special light.

28 Ibidem, 454 (strophe 25). 
It seems that references to Saxony and its inhabitants, which are to be found in the above strophes, fully testify the fact. The sense of triumph and satisfaction combines with a relief that the whole process was successfully finalised. Consequently, the aura of safety (tirr tryggðar) should be understood in the same way; the aura which was to accompany the expansion of the Danish churches. The poet's words and allusions should be directly referred to the discontent which the decision to create a diocese in Lund must have caused in the Hamburg-Bremen Church. The local clergy were able to do any deeds that would protect their control over the Christianity in Scandinavia. Suffice it to recall the abduction of Eskil, Qzur's successor, in Germany in 1156. Hence my conviction that the reference of Erik's ecclesiastic achievements to Saxony was not only accidental but it was supposed to fulfil the expectations of the archbishop in the way he and the institution represented by him defined the events.

Another outstanding achievement of Erik was - according to Markús - his pilgrimage to Rome and the Holy Land. The skald devoted three fragments of his poem to the pilgrimage to Italy: ${ }^{29}$

Lýst skal hitt, es lofðungr fýstisk langan veg til Róms at ganga
- fylkir sá par friðland balkat Fenneyjar hlið - dýrð at nenna. ${ }^{30}$

Now I'll talk about the ruler who wanted to travel to Rome to join his glory; there the ruler saw the protected land of peace, the gates of Venice.

Bróðir gekk í Bǫr út síðan

- bragningr vildi guðdóm magna - (hylli guðs mun hlífa stilli) hǫfuðskjǫldunga fimm (at gjǫldum). ${ }^{31}$

Then the brother of five kings went to Bari, the ruler wanted to strengthen the Kingdom of God; instead, God in his kindness will protect the Prince.

Stóra sótti Haralds hlýri

helga dóma út frá Rómi,

hringum varði áttkonr yngva

auðig skrín ok golli rauðu; mildingr fór of munka veldi móðum fœeti sǫl at bœta, sveitir kníði allvaldr útan, Eirekr vas til Róms í peiri. ${ }^{32}$

\footnotetext{
29 Strophes 8-10. The first two are actually half-strophes and originally they could have been a separate strophe.

30 SPMA II, 439 (strophe 8).

31 Ibidem, 441 (strophe 9).

32 Ibidem, 442 (strophe 10).
} 
Harald's brother visited the holy places outside Rome, the descendant of the king decorated the rich chapels with rings and red gold; generous he passed on foot the country of monks to redeem his soul, a powerful ruler encouraged his people to travel, Erik went to Rome then.

Similarly, as in the case of creating the archdiocese in Lund, the royal pilgrimage to Italy became an occasion to enhance Erik's status. In the above strophes the poet quite often refers to the king's brothers who ascended the Danish throne before him (bróðir fimm hofuðskjoldunga, hlýri Haralds, áttkonr yngva) ${ }^{33}$ and presents Rome as a perfect power. According to Markús Erik makes a pilgrimage to the country of monks (munka veldi),${ }^{34}$ which appears as a protected country of peace (friðland balkat). Also outside Rome, Erik had the occasion to visit numerous holy places (helga dóma). The message conveyed in these strophes is quite obvious. Under the rule of Erik, like before under the rule of his brothers, Denmark is to become a place that approaches the ideal that is Rome, a place of peace where people can glorify God and look for their road to redemption. The key role in that endeavour was played by the word dómr, which Markús used in strophes 9 and 10. Although the constructions guðdómr and helga dómar have a clear religious connotation, they are based on the word, which contains the meaning of 'power', 'court'. The effect produced by the skald must have satisfied the public in Lund who wanted to emphasise the relation between the royal power with the new religious centre.

Erik wanted also to go to the Holy Land, but he did not achieve the aim because of his illness, which ended up with his death in Cyprus. Thus the culminating point, full of religious elation, of the pilgrimage was the visit to Constantinople and the meeting with Emperor Alexios. ${ }^{35}$

Almost one third of the strophes of Eiriksdrápa are dedicated to the hostility of the Danish king towards the pagan Slavs. So intense concentration of the poet on that theme clears up all the doubts whether that motif, as all the other ones, was to contribute to the fame of Erik as a Christian ruler or not. We learn about the struggles of the Danish king with the Slavs from two groups of strophes. The first two strophes (4 and 6) are included in the fragment of the poem, where Markús

33 Although it is to be noted that similar ones appear also in other strophes of the poem $(4,21,24)$.

34 A similar phrase, munka valdi (ruler of monks), to describe God, is to be found in one of the strophes of Knútsdrápa by Hallvarda Hareksblesi. Cf. K.E. Gade, E. Marold eds., Scandinavian Poetry of the Middle Ages, Poetry from Treaties on Poetics, vol. 1 (Turnhout 2017), 238.

35 SPMA II, 455-457 (strophes 26-28). 
concentrates on the merits of the ruler and the circumstances, in which he ascended the throne after his brother Olaf's death:

Vár ǫndurt bjó Vinða rýrir

veglig flaust ór Gọrðum austan,

hlýrum skaut á hola bọru

helmings oddr í sumars broddi; hlýðu studdi borðvið breiðan bróðir Knúts í veðri óðu, síðan knátti svikfolks eyðir snilli kenndr við Danmǫrk lenda. ${ }^{36}$

Come spring, the one who destroys the Slavs prepared magnificent boats to navigate to Rus, at the beginning of summer the leader of the troops launched the prows (of the boats) on twisted sea waves; Knud's brother protected the wide side plating against water during stormy weather, the one who destroys traitors, full of wisdom, pulled in to the Danish coasts.

Vọrgum eyddi Vinða fergir, víking hepti konungr fíkjum, pjófa hendr lét pengill stýfa, pegnum kunni ósið hegna; aldri frásk, at Eirekr vildi allréttligum dómi halla, họla kunni sér til sælu sigrs valdari guðs logg halda. ${ }^{37}$

The one who destroys the Slavs defeated the outlaws, the king reduced piracy with all his strength, the ruler ordered that thieves would have their hands cut off, he knew how to punish people for their immoral deeds; Erik was never heard to have announced an unfair verdict, the ruler of victories knew how to follow God's orders for his sake.

Both epithets of the ruler - Vinða rýrir and Vinða fergir - functioned in a specific and interesting context. Markús, as mentioned above, dedicates the strophes in question to justify Erik's right to the throne and to show the quality of his rule. The skald concentrated on presenting his hero as a just ruler, eager to defend law and order and to eliminate anybody who would be against it. In this context, particularly the overtones of strophe 6 speak for themselves. The epithets concerning the Slavs were to enhance the strength of the message twofold. The poem is full of commendation for Erik's deeds, at sea (strophe 4) or towards his subjects (strophe 6). Hence, the obvious conclusion that according to the poet the king was equally effective towards the Slavs. The epithets Vinða rýrir and Vinða fergir have equivalents in the poetry of skalds, which were analysed by me somewhere else. Like in

\footnotetext{
36 Ibidem, 436 (strophe 4).

37 Ibidem, 438 (strophe 6).
} 
the case of Eiriksdrápa they did not refer directly to the actions against the Slavs but they played the role of synonyms of effectiveness and luck - mainly the military one - necessary on other occasions. A good example is the epithet Vinðum háttr (the one who threatens the Slavs), which was used by Sigvatr Pórðarson in front of Olaf Haraldsson describing his participation in the siege of Canterbury by the Danish in $1011 .{ }^{38}$ Yet there is no doubt that the rhetorical effectiveness of such epithets must have been based on the memory of the notable actions of the hero of the poem against the Slavs; the actions that might be presented as victorious. Markús's poem was just such a case, which will be discussed below. Anyway it is possible that the author of Eiriksdrápa, who must have known the poetry of Hallfreð Ottarsson, Sigvat Pórðarson and other poets, was inspired by their message while creating the above mentioned epithets of the hero of his poem.

In both strophes the skald puts at the same level the Slavs and traitors, thieves and pirates, who break God's laws and are a threat to the authority of the king and the happiness of his subjects. The Slavs, as pagans and organisers of incursions into the Danish lands perfectly fitted the above presented profile. The importance of that motif is confirmed by the fact that Markús begins both the strophes with the above mentioned epithets. The skald's intention might have been to impress the public and make them think the lack of mercy on the Slavs was the best definition of the just and pious rule of Erik in Denmark. At the same time, as in the case of using twin epithets, the phrases Vinða myrdir and Vinðum háttr were to strike the public by their bluntness and explicitness, which allowed the skald to be laconic.

Yet Markús does not content himself with that. The middle part of the poem contains 9 strophes (13-21), which are fully dedicated to Erik's military confrontations with the Slavs:

Veldi porðut Vinðr at halda, - villa gerðisk peim at illu -
- sunnan kom pá svikdómsmanna sáttarof - pats buðlungr átti.

The Slavs did not dare to regain control over the kingdom, which was taken over by the ruler; that mistake was a real tragedy for them, then the news spread about violating peace by treacherous people from the South.

38 J. Morawiec, "Vinða myrðir, Vindum hattr. Najazdy skandynawskich hovdingów na ziemie Słowian w świetle wierszy skaldów”, Przegląd Historyczny 4 (96) (2005): 525-541. 
Yngvi helt í óðastrǫngum

hlýða skalf, en hristi grœðir

oldugangi skipum pangat, hélug bǫrð fyr Vinða gǫrðum.

The king led his boats there when the waves were full of fury, the deck was shaking and the ocean threw the boat prows ashore, near Slavic settlements.

Rọndu lauk of rekka kindir

hamalt - knǫttu pá hlífar glymja risnumaðr, svát hver tók aðra, hildingr fylkði liði miklu.

The brave men surrounded the warriors' descendants with shields, so each one was joined with the next one; the ruler commanded his magnificent army in wedge array, then the shields started sounding.

Styrjǫld óx of stilli ǫrvan, mildingr gekk at miklum hjaldri stengr bǫru framm vísa drengir, malmi skrýddr ok faldinn hjalmi.

The battle broke out around the generous ruler, his warriors carried banners forwards; the generous ruler followed them, dressed in metal and helmet, into the great tumult.

Họrga varðisk herr í borgum, hjaldrganga vas snǫruð pangat, harðir kníðusk menn at morði, merki blés of hilmi sterkan;
Eirekr vakði odda skúrir, eggjar týndu lífi seggja, sungu jǫrn, en sœeðusk drengir, sveiti fell á valkǫst heitan.

The army of pagan temples defended themselves in their fortresses, the battle soon flared up, the furious warriors pushed forwards to slaughter, the banner fluttered around the strong prince; Erik incited a flood of arrowheads, the arrowheads destroyed human lives, the weapons sounded and the warriors died, the blood was streaming down the pile of corpses.

Blóði dreif á randgarð rauðan, rógs hegnir drap ótal pegna, framði sik, pars folkvǫpn glumðu, fylkir ungr, en brynjur sprungu.

The blood gushed onto the red wall of shields, the one who punishes any disorder took the life of innumerable people; the young ruler stood out there, where the battle weapons sounded and the chain mail garments broke.

Heiðinn vildi herr of síðir

urðu peir, es virki vǫrðu

hǫmlu vígs ór porti gǫmlu, vangi næst, á họnd at ganga. 
The pagan army of the battle flagpole finally decided to leave the old fortress; the ones who had defended the fortress near the plain, had to surrender.

Heiðin vǫru hjǫrtu lýða

hryggðarfull í Vinða byggðum,

eldi sveif of ótal haulda,

Eirekr brenndi sali peira; eisur kyndusk họtt í húsum, hallir nǫðu vítt at falla, óttu leið, en uppi pótti elris grand í himni standa.

The pagan hearts were full of sadness among the Slavic settlements, the fire was creeping up the innumerable hosts, Erik burnt their halls; the flames rose high, the halls collapsed one after another, the night passed and the one who hurts the wood seemed to reach the sky.

Eirekr vas með uppreist hǫri, undan flýðu Vinðr af stundu, gjǫld festu pá grimmir hauldar, gumnar urðu sigri numnir; yngvi talði erfðir pangat, alpýða varð stilli hlýða, veldi réð pví ástvinr aldar einart, lá pat fyrr und Sveini. ${ }^{39}$

Erik achieved a great success, the Slavs fled thence without delay, the furious hosts declared a tribute, they were deprived of the victory; the king announced there his right to the heritage, all the people had to surrender to the ruler, the adored friend of people ceaselessly ruled the kingdom, which before was subdued to Sven.

The above quoted set of strophes is an extension of the contents, which appeared at the beginning of the poem, in strophes 4 and 6 . The king proves his effectiveness in establishing law and order by positive actions aimed at the pagan Slavs. Markús presents Erik as a victorious leader, merciless for his enemies and generous for his troops. The distinctive elements in the image of the king of Denmark are his sense of justice (hegnir rógs) on the one hand, and on the other his determination in achieving his goals. According to Markús the king pays no heed to the bad weather and sets out southwards as soon as he gets news about the Slavs' treason.

The attitude of the king was to be dictated by the ensuing stake. Firstly, the Slavs, as traitors (svikmenn) and pagans (heiðnar) were a threat to peace in the kingdom to the same degree as all the other villains. Secondly, according to the poet, the struggles in the south served Erik as an excuse to show his rights to the kingdom of Denmark (talði erfðir). Defeating the Slavs, pagans and other

39 SPMA II, 444-450. 
enemies Erik proved that he obeyed God's laws and in that way he passed a test to be an effective ruler, who deserved the respect of his subjects (alpýða varð hlýða stilli). Hence Markús without hesitation crowns this part of his poem with the words of the great success (hár uppreist), which Erik achieved. ${ }^{40}$

Markús in Eiriksdrápa used stylistic solutions that attract attention. Erik's action towards the Slavs were dictated by the treason (svik) they had committed against the king. The skald does not give us many details, we only learn that pagans from the south were to break peace. The term svik becomes the key word in this context. It not only motivates Erik, but also describes the ones who turned out to be his enemies. The Slavs are svikmenn, and the territories where they live may be called svikdómr, i.e. the land of treason. ${ }^{41}$ This term to denominate Slavdom, somehow original, should be juxtaposed with guðdómr and helga dómar, which Erik visited during his pilgrimages. The latter two terms were synonyms of a perfect regime based on God's laws and peace, whereas the Slavic territories were just the reverse. Hence the different actions of the ruler, although it should be admitted that Markús made a big effort to convince the addressees of the poem that Erik was equally involved in his fight against pagans and in his pilgrimages to holy places.

The term svikdómr seems to be Markús's own invention, whereas the concept of treason, which the hero faces, had already appeared in the poetry of the skalds. The clearest analogies, which might have been inspiring for the author of Eiriksdrápa, were supplied by the poetry of Hallfreð Ottarsson and Sigvat Pórðarson. The former in a poem dedicated to the struggles of Olaf Tryggvason in Øresund in 1000 (Óláfsdrápa erfidrápa Tryggvasonar) says in one of the strophes that the

40 The second helming of strophe 21 crowns a reference to Swen, who was to rule the Danish kingdom before. The author of Knýtlinga saga perceived him as Sweyn Forkbeard. Jayne Carroll in a justified way (SPMA II, 450) questions the rightness of such identification, but she refers only to the lack of any reliable information on any command of Sweyn Forkbeard over the Slavs. This argument seems ex definitione pointless. Markús speaking about pví veldi might have meant Denmark, and in Sweyn I'd rather see Swen Ulfsson, Erik's father. The contents of the helming (or rather the whole strophe) would refer to the right to rule Denmark, which the hero of the poem inherited from his father. Such identification is compatible with numerous references to Erik's particular brothers, which may constitute a quite close echo of the controversies and conflicts in the dynasty, first of all among Swen Ulfsson's sons, over the succession to the throne.

41 Jayne Carroll - in my opinion rightly - identifies the term svikfolk, which was used by the skald in strophe 4 concerning the Slavs, cf. SPMA II, 437. It should be said that the phrase svikdomr does not appear in any other place but in Markús's poem. Contrary to the proposal of Carroll (Ibidem, 444), who associates this adjective with the adverb 'treacherous', I would be inclined all the more strongly to see that term as an expression of a will to juxtapose - in a clear way, revealing a straight out catechetical dimension - of negative and positive 'regimes' (dómar), Erik dealt with. 
king of Norway was defeated and died because of the treason on the part of his warriors..$^{42}$ In turn, Sigvatr, in strophe 2 of Vikingarvisur used the motif in question to justify the Viking action of Olaf Haraldsson towards the inhabitants of Ozylia, who committed treason that the king could not forgive ${ }^{43}$. In this context the second case is even more interesting because Sigvatr, like Markús, wanted to depict the pirate activity of Olaf as a sign of his royal prerogatives.

As the punishment for the treason committed by the Slavs they had to be killed and their settlements burnt. That motif dominated strophe 20 of Eiriksdrápa. The skald's picture is extraordinarily expressive and vivid, which was to impress the receivers of the poem. One more time Markús skilfully showed the causative strength of the king: Eirekr brenndi peira sali. The rules of the runhent metre, first of all the higher number of syllables in a line, allowed the words of the poet to sound better and more bluntly. In this aspect a potential source of inspiration for the author of Eiriksdrápa may be also identified. The above mentioned motif of punishing for treason with fire may be quite frequently found in the skalds' poetry of the 11th century, still Arnór Pórðarson's account of the incursion into Wolin in 1043 by Magnus the Good (den Gode) seems to be of key importance in this context. The author of two poems dedicated to the king of Norway and Denmark, Hrynhenda and Magnússdrápa, used exactly the same elements: pagans' hearts filled with fear of the king, vivid descriptions of the fire burning the Slavs' settlements, who were punished for their dishonourable misdeeds. It has been well depicted by strophe 8 of Magnússdrápa:

Vann, pás Venðr of minnir, vápnhríð konungr síðan, sveið of om at Jómi

illvirkja hræ stillir; búk dró bráðla steikðan blóðugr vargr af glóðum, rann á óskírð enni allfrekr bani hallar. ${ }^{44}$

The king triggered off a storm of weapons, which the Slavs remember, the ruler burnt many a corpse of villains in Jomsborg; a bloody wolf carried away the burnt body from the burnt-down house; the worst death was climbing up the pagans' foreheads in the hall with a fire.

42 Cf.: Morawiec, Między poezja, 292-294.

43 Ibidem, 325-326.

44 SPMA II, 217; cf.: J. Morawiec, Wolin w średniowiecznej tradycji skandynawskiej (Cracow 2010), 448 and the following pages. 
The rhetoric of that account is so close to the way Markús depicted Erik's action against the Slavs that it would be difficult not to interpret it as a result of direct inspiration. Taking into consideration the Danish rule of Magnus and its legitimisation based on his father's intercession, Olaf the Saint, it is justified to say that Magnus the Good, probably not only with reference to his military confrontations with the Slavs, was to serve as a model for Erik as the king, and in the same way Arnór's poetry was to serve as a model for Markús.

Last but not least, it should be emphasised that in spite of the fact that the motif of Erik's battles against the Slavs occupies a prominent place in Eiriksdrápa, in the skald's account there are no interesting details up to the standards reached in the descriptions of the king's pilgrimages or of his efforts to establish the archdiocese in Lund. This riddle might be explained in the following way: a worse world, a world of pagans, treasons and villains did not deserve such a dignified treatment as - in Markús's own words - a safely protected empire of monks, full of holy places. Actually, the explanation might be quite different. The skald wanted to present Erik's achievements in the way that would meet the expectations of the receivers of the poem, the political and ecclesiastical elites of Denmark, so undoubtedly he had to collect information on the events the picture of the late king was built of, but the access to that information was difficult. As a result it is easy to identify in Eiriksdrápa such elements as the references to Saxony, the number of funded churches, a list of monarchs the late king had contact with, and a list of places he visited as a pilgrim. Markús was able to gather such information only by using the knowledge and memory of the ones who had known the king and cooperated with him. As I have already mentioned, the key role might have been played by the mediation of Jón Qgmundarsson, who had a vested interest in Markús's poem having the best possible effect.

In the case of Erik's struggles against the Slavs, the skald did not need any help. While composing Eiriksdrápa Markús took advantage of the oeuvre of Arnór Pórðarson and of other poets. The poems of the former, who like Sigvat Pórðarson, seems to be the main source of the poetic inspiration for Markús, could supply the latter with everything he needed, first of all ready-made motifs of the treacherous pagan Slavs and an ardent Christian ruler who effectively eliminated the threat posed by them. It was sufficient to achieve the effect which the skald was interested in. Thus, although Markús's rhetoric concerning the Slavs might be assessed as stereotypical and not very sophisticated, it seems that, like other motifs, it fitted the expectations of the receivers of the poem. The image of pagan 
traitors who deserved to be punished, which is revealed in Eiriksdrápa, properly rendered the atmosphere in the borderland between Denmark and the Slav lands at the turn of the 11th and 12th centuries. On the other hand, that image was a result not of the will to have a proper look at the neighbours south of Erik's domain but it was rather an effect of uncritical imitating the poetic authority and a will to equal him in the skaldic trade.

\section{Bibliography}

\section{Sources}

Benediktsson J. ed., Íslendingabók, Landnámabók. Reykjavík: Íslenzk fornrit 1, 1968.

Gade K.E. ed., Scandinavian Poetry of the Middle Ages, Poetry from the Kings' Sagas 1. From c. 1035 to c. 1300. Vol. 1-2. Turnhout, 2009.

Gade K.E., Marold E. eds., Scandinavian Poetry of the Middle Ages, Poetry from Treaties on Poetics. Vol. 1. Turnhout, 2017.

Grønlie S. ed., Íslendingabók, Kristni saga. London, 2006.

Sigurðsson J. et al., eds., Edda Snorra Sturlusonar. Edda Snorronis Sturlaei. Vol. 3. Copenhagen 1887.

\section{Studies}

Gelting M.H. "The Kingdom of Denmark". In: Christianization and the Rise of Christian Monarchy. Scandinavia, Central Europe and Rus' c. 900-1200, ed. N. Berend. Cambridge, 2007.

Gudnason B. "Saxo och Eiríksdrápa". In: Nordiska studier i filologi och lingvistik. Festskrift tillägnad Gösta Holm på 60-årsdagen den 8 juli 1976, eds. L. Svensson et al. Lund, 1976.

Jesch J. "'Youth on the Prow'. Three Young Kings in the Late Viking Age". In: Youth in the Middle Ages, eds. P.J.P. Goldberg, F. Riddy. York, 2002.

Jesch J. "Old and New in Markús Skeggjason's Eiríksdrápa". In: Scandinavia and Christian Europe in the Middle Ages. Papers of the 12th International Saga Conference Bonn/Germany, 28th July - 2nd August 2003, eds. R. Simek, J. Meurer. Bonn, 2003.

Morawiec J. "Slavs and their lands in Old Norse literature". In: Scandinavian Culture in Medieval Poland, eds. S. Moździoch, B. Stanisławski, P. Wiszewski. Wrocław, 2013. 
Morawiec J. "Vinða myrðir, Vindum hattr. Najazdy skandynawskich hovdingów na ziemie Słowian w świetle wierszy skaldów”. Przegląd Historyczny 4 (96) (2005).

Morawiec J. Między poezja i polityka. Rozgrywki polityczne w Skandynawii XI wieku $w$ świetle poezji ówczesnych skaldów. Katowice, 2016.

Morawiec J. Wolin w średniowiecznej tradycji skandynawskiej. Cracow, 2010.

Olsen M. “Lovsigemanden Markus Skeggesøns arvekvæde”. Edda 15 (1921).

Skovgaard-Petersen I. "The Making of Danish Kingdom”. In: The Cambridge History of Scandinavia. Volume 1, Prehistory to 1520, ed. K. Helle. Cambridge, 2003.

\title{
ILLVIRKJAR OK ÓSKÍRĐIR. EIRÍKSDRÁPA MARKÚSA SKEGGJASONA JAKO PRZYKŁAD WYKORZYSTANIA MOTYWU SLOWIANINA-POGANINA W ŚREDNIOWIECZNEJ LITERATURZE SKANDYNAWSKIEJ
}

Słowa kluczowe: poezja, pogaństwo, Słowianie

\begin{abstract}
Abstrakt
Tematem artykułu jest Eiríksdrápa islandzkiego poety Markúsa Skeggjasona, wiersz poświęcony pamięci króla Danii Eryka Zawsze Dobrego (1095-1103). Poemat uświetnił wizytę Jóna Qgmundarsona w Lund w 1105 roku, gdzie miejscowy arcybiskup Gizurr wyświęcił go na biskupa Hólar. Wiersz sławi przede wszystkim te dokonania króla Eryka, które wskazywały na chrześcijański wymiar jego rządów. Świadczyć o tym miały zarówno uzyskanie zgody papieża na erygowanie archidiecezji w Lund, jak i pielgrzymi króla do Rzymu i Ziemi Świętej. Wpisuje się w to również motyw wrogich działań Eryka wobec pogańskich Słowian, co zajmuje w wierszu Markúsa poczesne miejsce i jest głównym przedmiotem analizy w artykule. Motyw ten ukazuje Słowian jako zdrajców (svikmenn) i pogan (heiðnar) zagrażająych pokojowi w królestwie. Brak litości dla nich ze strony Eryka dowodził jego sprawiedliwych i bogobojnych rządów w Danii. Analizowany motyw dowodzi jego przydatności w procesie kształtowania wizerunku chrześcijańskiego władcy, wskazuje także na warsztat artystyczny Markúsa, oparty w głównej mierze na dorobku innych poetów, także opisujących pogańskich Słowian.
\end{abstract}

